\title{
Tingkat dan laju penurunan kualitas air di DAS Brantas Malang Raya
}

\author{
Ima Yudha Perwira a* \\ a Program Studi Manajemen Sumberdaya Perairan, Fakultas Kelautan dan Perikanan, Universitas Udayana, Kampus UNUD Bukit Jimbaran \\ 80361, Bali, Indonesia \\ * Penulis koresponden. Tel.: +62-812-1738-9998 \\ Alamat e-mail: ima.yudha@unud.ac.id
}

Diterima (received) 26 November 2018; disetujui (accepted) 12 Januari 2019; tersedia secara online (available online) 13 Januari 2019

\begin{abstract}
The decrease level of water quality of Brantas Watershed in Malang Raya was observed in this study. The aim of this study was to observe the decrease level of water quality of Brantas Watershed from Batu to Malang City. This study was carried out in the Brantas Watershed of Malang Raya (8 stations: A, B, C, D, E, F, G, and H) for 18,4 Km. The water quality parameters observed in this study were: CODmn (permanganometry), CODcr (CODmn correlation based analysis), dissolved oxygen (DO) (Winkler iodometry), TDS and electrical conductivity (EC) (EC meter), $\mathrm{pH}$ ( $\mathrm{pH}$ meter), and turbidity (Turbidity meter). The result showed the value of CODmn: 1,8-10,2 mg/L, CODcr: 5,6-31,5 mg/L, DO: 4,0-6,1 mg/L, TDS: 204-289 mg/L, EC: 430-617 $\mu$ S/cm, pH: 7,1-7,6, and turbidity: 2,02-10,30 NTU. There are 3 stations (A, B, and C) with 1st class water quality, 1 station (D) with the 2nd class water quality, and 4 stations (E, F, $\mathrm{G}$, and $\mathrm{H}$ ) with 3rd class water quality. The decrease of water quality in the Brantas Watershed from Batu to Malang City was up to 3 times with a decrease rate of $2,3 \mathrm{mg} / \mathrm{L}-1 \mathrm{Km}-1$. The decomposition of organic materials in the water of Batu City and western part of Malang City is relatively better than that of central parts of Malang City which might be caused by the over capacity of recovery (Self-purification mechanism).
\end{abstract}

Keywords: decrease rate of water quality; watershed; Brantas River; Batu City; Malang City

\begin{abstract}
Abstrak
Tingkat dan laju penurunan kualitas air di Daerah Aliran Sungai (DAS) Brantas Malang Raya telah berhasil diamati pada penelitian ini. Tujuan dari penelitian ini adalah untuk mengetahui penurunan kualitas air di DAS Brantas dari Kota Batu sampai Kota Malang. Penelitian dilakukan di DAS Brantas yang mengalir dari Kota Batu sampai Kota Malang (8 titik lokasi: A, B, C, D, E, F, G, dan H) sepanjang 18,4 Km. Adapun parameter kualitas air yang diamati antara lain adalah: CODmn (permanganometri), CODcr (analisa korelasi dengan CODmn), DO (Winkler iodometri), TDS dan electrical conductivity (EC) (EC meter), $\mathrm{pH}$ ( $\mathrm{pH}$ meter), dan turbidity (Turbidity meter). Hasil penelitian menunjukkan bahwa nilai CODmn: 1,8-10,2 mg/L, CODcr: 5,6-31,5 mg/L, DO: 4,0-6,1 mg/L, TDS: 204-289 mg/L, EC: 430-617 $\mu \mathrm{S} / \mathrm{cm}, \mathrm{pH}:$ 7,1-7,6, dan turbidity: 2,02-10,30 NTU. Terdapat 3 titik (A, B, dan C) yang kualitas airnya masuk dalam Kelas 1 ambang baku mutu kualitas air, 1 titik (D) masuk dalam Kelas 2, dan 4 titik (E, F, G, dan H) masuk dalam Kelas 3. Telah terjadi penurunan kualitas air sungai sebesar hampir 3 kali lipat dari Kota Batu sampai Kota Malang, sedangkan laju penurunan kualitas airnya sebesar 2,3 mg/L-1Km-1. Tingkat dekomposisi bahan organik pada air sungai di wilayah Kota Batu dan Malang bagian barat masih cukup baik, sedangkan di pusat Kota Malang sudah menurun jauh dan melewati titik jenuh kemampuan recovery-nya (self-purification mechanism).
\end{abstract}

Kata Kunci: tingkat penurunan kualitas air; DAS; Sungai Brantas; Kota Batu; Kota Malang.

\section{Pendahuluan}

Sungai Brantas merupakan salah satu sungai terpanjang di Pulau Jawa. Berawal dari Desa
Brantas (Kota Batu), sungai ini mengalir ke beberapa wilayah di Jawa Timur (Malang, Blitar, Tulungagung, Kediri, Jombang, dan Mojokerto). Di Mojokerto, Sungai ini terbagi menjadi dua 
aliran menuju ke Sungai Porong (Sidoarjo) dan Sungai Kalimas (Surabaya). Sungai Brantas memiliki peran yang penting untuk beberapa wilayah di area Propinsi Jawa Timur. Beberapa Kabupaten dan Kota di wilayah Propinsi Jawa Timur memanfaatkan aliran air dari Daerah Aliran Sungai (DAS) Brantas ini untuk berbagai kebutuhan. Terdapat dua jenis pengguna air yang berasal dari DAS Brantas ini. Pengguna pertama adalah kelompok pengguna yang memanfaatkan air untuk kepentingan komersial, antara lain: kebutuhan Perusahaan Daerah Air Minum (PDAM), Perusahaan Listrik Negara (PLN), dan industri. Sedangkan pengguna berikutnya adalah kelompok pengguna yang memanfaatkan air untuk kepentingan non komersial yaitu untuk kebutuhan pertanian dan rumah tangga (Sylviani, 2008; Bappeda Kabupaten Blitar, 2015; Baidlowi, 2017). Kuantitas dan kualitas air yang mengalir di Sungai Brantas tentunya menjadi hal yang krusial untuk diperhatikan demi memenuhi seluruh kebutuhan ini.

\section{Tabel 1}

Titik lokasi pengambilan sampel

\begin{tabular}{cll}
\hline Titik & Koordinat & Lokasi \\
\hline A & $7^{\circ} 52^{\prime} 32,4^{\prime \prime} \mathrm{N}, 112^{\circ} 33^{\prime} 22,7^{\prime \prime} \mathrm{E}$ & Bumiaji-Batu \\
B & $7^{\circ} 53^{\prime} 46,2^{\prime \prime} \mathrm{N}, 112^{\circ} 34^{\prime} 21,8^{\prime \prime} \mathrm{E}$ & Bumiaji-Batu \\
C & $7^{\circ} 57^{\prime} 22,7^{\prime \prime} \mathrm{N}, 112^{\circ} 37^{\prime} 29,0^{\prime \prime} \mathrm{E}$ & Lowokwaru-Malang \\
D & $7^{\circ} 57^{\prime} 42,0^{\prime \prime} \mathrm{N}, 112^{\circ} 37^{\prime} 34,5^{\prime \prime} \mathrm{E}$ & Klojen-Malang \\
E & $7^{\circ} 58^{\prime} 45,9^{\prime \prime} \mathrm{N}, 112^{\circ} 37^{\prime} 56,4^{\prime \prime} \mathrm{E}$ & Klojen-Malang \\
F & $7^{\circ} 58^{\prime} 57,8^{\prime \prime} \mathrm{N}, 112^{\circ} 38^{\prime} 14,8^{\prime \prime} \mathrm{E}$ & Belimbing-Malang \\
$\mathrm{G}$ & $7^{\circ} 59^{\prime} 24,7^{\prime \prime} \mathrm{N}, 112^{\circ} 38^{\prime} 32,1^{\prime \prime} \mathrm{E}$ & Belimbing-Malang \\
$\mathrm{H}$ & $7^{\circ} 59^{\prime} 54,6^{\prime \prime} \mathrm{N}, 112^{\circ} 38^{\prime} 15,4^{\prime \prime} \mathrm{E}$ & Kedungkandang- \\
\hline
\end{tabular}

Dalam beberapa dekade terakhir, muncul berbagai permasalahan terkait dengan kuantitas dan kualitas air di DAS Brantas. Data terbaru menyatakan bahwa terjadi penyusutan produksi sumber mata air di bagian hulu DAS Brantas, yang menurun dari $10 \mathrm{~m}^{3} /$ detik hingga kurang dari 5 $\mathrm{m}^{3} /$ detik (Sulistyaningsih et al., 2017). Selain itu, seiring dengan pertambahan populasi penduduk, terjadi optimalisasi lahan di sekitar DAS Brantas yang digunakan untuk berbagai aktifitas antropogenik. Indikasi yang tampak dari adanya penurunan kualitas air ini adalah tingginya tingkat kekeruhan air yang ada di beberapa lokasi DAS Brantas di Malang Raya (Bahriyah et al., 2018).
Indikasi lain dari penurunan kualitas air atau pencemaran yang ada di Sungai Brantas adalah penurunan keragaman makrozoobentos invertebrata dan indeks biotiknya (Retnaningdyah dan Arisoesilaningsih, 2014). Oleh karena itu, diperlukan suatu kajian atau evaluasi tentang tingkat penurunan kualitas air di DAS Brantas yang ada di Malang Raya. Hasil dari kajian ini diharapkan dapat memberikan gambaran lengkap mengenai status kondisi kualitas air yang ada di DAS Brantas Malang Raya.

\section{Metode Penelitian}

\subsection{Lokasi penelitian}

Penelitian ini dilakukan di DAS Brantas yang berlokasi di Malang Raya (Kota Batu dan Kota Malang. Sepanjang 18,4 Km yang diteliti, diambil 8 titik (Tabel 1). Pengambilan sampel air dilakukan pada awal musim hujan (November 2018).

\subsection{Pengambilan sampel air}

Sampel air sungai diambil dengan menggunakan water sampler. Air sampel tersebut kemudian disimpan dalam botol sampel dan disimpan pada suhu dingin $\left(4^{\circ} \mathrm{C}\right)$ sampai dilakukan analisa. Proses analisa kualitas air dilakukan dalam waktu tidak lebih dari 24 jam untuk menghindari perubahan kondisi sampel air.

\subsection{Pengukuran kualitas air}

\subsubsection{Kebutuhan oksigen kimiawi (COD)}

Kebutuhan oksigen kimiawi (COD) pada air sungai diukur dengan menggunakan metode permanganometri (Japan Industrial Standards / JIS K0102). Sampel air sungai (100 mL) dicampurkan dengan larutan $\mathrm{H}_{2} \mathrm{SO}_{4}(10 \mathrm{~mL}), \mathrm{KMnO}_{4}(10 \mathrm{~mL})$, dan $\mathrm{Ag}_{2} \mathrm{SO}_{4}(0,2 \mathrm{~g})$. Larutan tersebut kemudian dipanaskan pada suhu $100^{\circ} \mathrm{C}$ selama 30 menit. Setelah itu, dilakukan titrasi dengan menggunakan larutan $\mathrm{KMnO}_{4}$ sampai terjadi perubahan warna dari jernih menjadi merah muda. COD air sungai dapat diketahui melalui formula berikut:

$$
\text { CODmn }=(\text { Vol. } A-\text { Vol.B }) \times 1 \times \text { Pengenceran } \times 0,2
$$

dimana $A$ adalah Volume titrasi sampel; B adalah Volume titrasi blanko; dan 0,2 adalah Faktor pengali $\mathrm{O}_{2}$ dalam $\mathrm{KMnO}_{4}$. 
Nilai CODcr yang merepresentasikan nilai COD secara dikromat diestimasikan dengan menggunakan grafik korelasi linier $(\mathrm{y}=3,091 \mathrm{x})$ (Choi et al., 2014). Nilai CODcr dalam persamaan tersebut direpresentasikan sebagai $\mathrm{y}$, sedangkan nilai CODmn direpresentasikan sebagai $x$.

\subsubsection{Oksigen terlarut (DO)}

Kandungan oksigen terlarut dalam air sungai diukur dengan menggunakan metode Winkler secara yodometri (SNI 06-6989.14-2004). Sampel air sungai $(300 \mathrm{~mL})$ dimasukkan ke dalam botol winkler, kemudian ditetesi dengan larutan $\mathrm{MnSO} 4$ dan alkali yodida azida masing-masing $2 \mathrm{~mL}$. Larutan tersebut kemudian dihomogenkan hingga terbentuk gumpalan, dan dibiarkan mengendap selama 5-10 menit. Selanjutnya, ditambahkan larutan $\mathrm{H}_{2} \mathrm{SO}_{4}$ pekat sebanyak $1 \mathrm{~mL}$ ke dalam botol winkler yang berisi larutan sampel tersebut, dan dihomogenkan hingga endapan larut secara sempurna. Larutan dari dalam botol winker tersebut kemudian diambil sebanyak $50 \mathrm{~mL}$ dan dimasukkan ke dalam sebuah botol erlenmet 150 $\mathrm{mL}$. Indikator amilum ditambahkan ke dalam larutan tersebut hingga muncul warna biru, kemudian dititrasi dengan menggunakan larutan $\mathrm{N}_{2} \mathrm{~S}_{2} \mathrm{O}_{3}$ sampai warna biru hilang dan berubah menjadi berwarna jernih. Kandungan oksigen terlarut dihitung dengan menggunakan formula berikut:

$$
D O=\frac{V x N \times 8000}{50}
$$

dimana $\mathrm{V}$ adalah Volume $\mathrm{Na}_{2} \mathrm{~S}_{2} \mathrm{O}_{3}$ pada titrasi; dan $\mathrm{N}$ adalah Normalitas $\mathrm{Na}_{2} \mathrm{~S}_{2} \mathrm{O}_{3}$.

2.3.3. Total dissolved solid dan electrical conductivity

Total dissolved solid (TDS) dan electrical conductivity (EC) pada air sungai diukur dengan menggunakan Electrical Conductivity Meter (Lutron YK22CT) (Gustafson dan Behrman, 1939), yang dihasilkan melalui analisa korelasi linier (Rusydi, 2017). Pengukuran TDS dan EC dilakukan secara in situ dengan cara mencelupkan sensor alat ke dalam air sungai.

\subsubsection{Tingkat keasaman $(\mathrm{pH})$}

Tingkat keasaman $(\mathrm{pH})$ air diukur dengan menggunakan alat $\mathrm{pH}$ meter (Horiba B-212).
Sampel air sungai diteteskan ke dalam container sensor $\mathrm{pH}$ meter, kemudian tombol on/off alat ditekan untuk memunculkan nilai $\mathrm{pH}$ air.

\subsubsection{Kekeruhan (turbidity)}

Tingkat kekeruhan (turbidity) air sungai diukur dengan menggunakan turbidity meter (Lutron-TU 2016). Sampel air sungai (10 mL) dimasukkan ke dalam container kit, kemudian dimasukkan ke dalam alat turbidity meter. Tingkat kekeruhan air dibaca pada panjang gelombang $850 \mathrm{~nm}$, dan dinyatakan dalam satuan Nephelometric Turbidity Unit (NTU).

\section{Hasil}

\subsection{Kondisi umum kualitas air di Sungai Brantas}

Berdasarkan hasil pengamatan pada sampel air di Sungai Brantas dapat diketahui bahwa DO air berkisar tidak terdapat perbedaan yang tinggi antar titik pengamatan. Nilai DO berkisar antara 4,0 - 5,1 mg/L dari titik A sampai dengan titik $\mathrm{H}$. Pengukuran nilai COD di lokasi penelitian juga menunjukkan nilai yang bervariasi antara 2,4 - 6,6 $\mathrm{mg} / \mathrm{L}$. Nilai COD paling rendah ada pada titik A $(2,4 \mathrm{mg} / \mathrm{L})$, dan nilai COD tertinggi ditunjukkan pada titik $H$. Hasil pengamatan COD menunjukkan adanya kenaikan secara gradual dari titik A sampai dengan titik $\mathrm{H}$, yang mengindikasikan kenaikan kandungan organik maupun inorganik yang ada di dalam air sungai. Nilai TDS dan EC pada air sungai sangat bervariasi, yang berkisar antara $204-289 \mathrm{mg} / \mathrm{L}$ dan $430-617(\mu \mathrm{S} / \mathrm{cm})$. Nilai $\mathrm{pH}$ air sungai berkisar antara $7,1-7,6$, yang mengalami penurunan secara gradual dari titik A sampai titik $\mathrm{H}$. Turbidity air sungai juga mengalami kenaikan dari 2,02 NTU (titik A) sampai dengan 10,30 NTU (titik H).

Hasil analisa korelasi menunjukkan bahwa CODcr air sungai berkisar antara 5,6-31,5 mg/L. Nilai CODcr terendah ditunjukkan pada titik A (5,6 mg/L), dan nilai tertinggi ditunjukkan pada titik $\mathrm{H}(31,5 \mathrm{mg} / \mathrm{L})$. Berdasarkan hasil tersebut diketahui bahwa kualitas air di 3 titik (A, B, dan C) masuk dalam kelas 1 ambang baku mutu kualitas air menurut PP Nomor 82 Tahun 2001 tentang Pengelolaan Kualitas Air dan Pengendalian Pencemaran Air. Selain itu, 1 titik (D) masuk dalam kelas 2, dan 4 titik (E, F, G, dan H) masuk dalam kelas 3. Kondisi umum kualitas air di Sungai Brantas Malang dapat dilihat pada Tabel 2. 
Tabel 2

Kondisi kualitas air di DAS Brantas, Malang Raya

\begin{tabular}{|c|c|c|c|c|c|c|c|}
\hline Titik & $\begin{array}{c}\text { CODmn } \\
(\mathrm{mg} / \mathrm{L})\end{array}$ & $\begin{array}{c}\text { CODcr } \\
(\mathrm{mg} / \mathrm{L})\end{array}$ & $\begin{array}{c}\text { DO } \\
(\mathrm{mg} / \mathrm{L})\end{array}$ & $\begin{array}{c}\text { TDS } \\
(\mathrm{mg} / \mathrm{L})\end{array}$ & $\begin{array}{c}\mathrm{pH} \\
\text { Turbidity } \\
(\mathrm{NTU})\end{array}$ & $\begin{array}{c}\text { Kelas } \\
(\mathrm{COD} c \mathrm{r})\end{array}$ \\
\hline A & 1,8 & 5,6 & 6,1 & 220 & 7,6 & 2,02 & 1 \\
\hline B & 2,6 & 8,0 & 5,8 & 207 & 7,6 & 2,41 & 1 \\
\hline C & 1,8 & 5,6 & 5,8 & 251 & 7,7 & 2,55 & 1 \\
\hline D & 4,2 & 13,0 & 5,1 & 268 & 7,5 & 4,55 & 2 \\
\hline E & 9,0 & 27,8 & 4,5 & 289 & 7,3 & 4,37 & 3 \\
\hline F & 8,6 & 26,6 & 4,5 & 244 & 7,0 & 6,09 & 3 \\
\hline G & 9,4 & 29,1 & 4,3 & 258 & 7,0 & 6,71 & 3 \\
\hline H & 10,2 & 31,5 & 4,0 & 204 & 7,1 & 10,30 & 3 \\
\hline
\end{tabular}

\subsection{Kenaikan Turbidity dan COD air sungai}

Hasil pengamatan menunjukkan bahwa seiring dengan kenaikan turbidity air, diikuti dengan kenaikan COD air (Gambar 1A). Terdapat korelasi positif antara turbidity dan COD air $\left(\mathrm{R}^{2}=0,7309\right)$ (Gambar 1B). Kenaikan turbidity dan COD secara tajam ditunjukkan pada titik D, E, dan F, menunjukkan tingginya input material tersuspensi di lokasi itu.

\section{A}

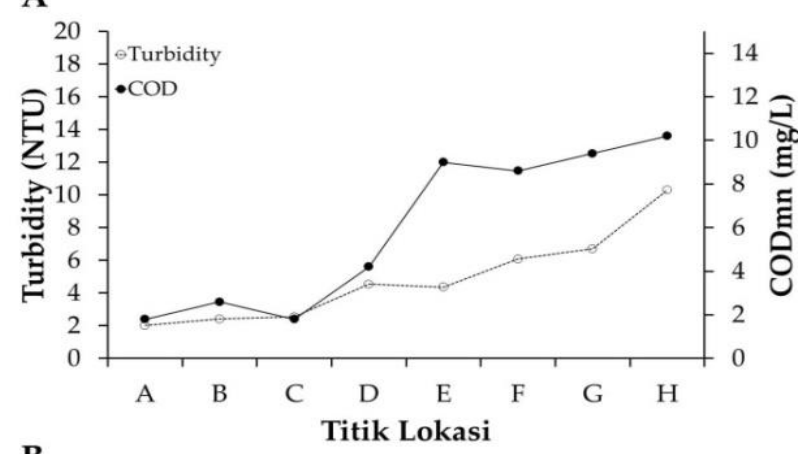

B

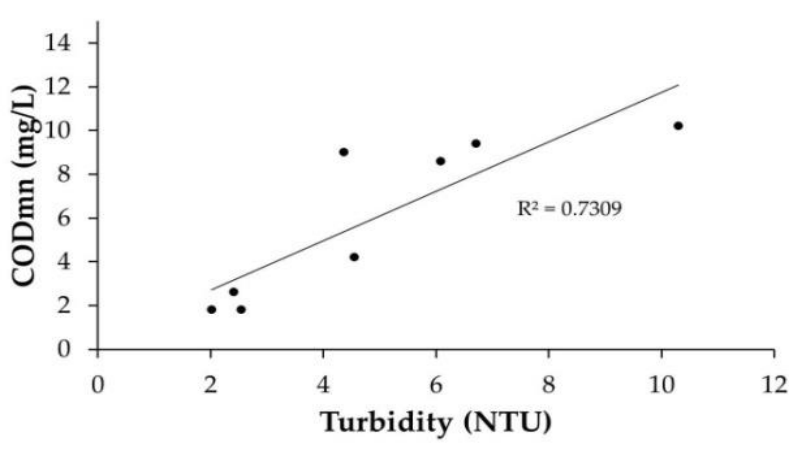

Gambar 1. Tingkat kenaikan (A) dan hubungan antara turbidity dan COD (B)

\subsection{Kenaikan COD dan penurunan $p H$ air sungai}

Hasil analisa COD dan $\mathrm{pH}$ air menunjukkan bahwa seiring dengan naiknya COD, terjadi penurunan $\mathrm{pH}$ (Gambar 2A). Hal ini mengindikasikan adanya korelasi antara kedua parameter kualitas air tersebut, dengan $\mathrm{R}^{2}=0,8724$ (Gambar 2B). Penurunan $\mathrm{pH}$ di air ini mengindikasikan adanya kenaikan ion $\mathrm{H}^{+}$di dalam air sungai.

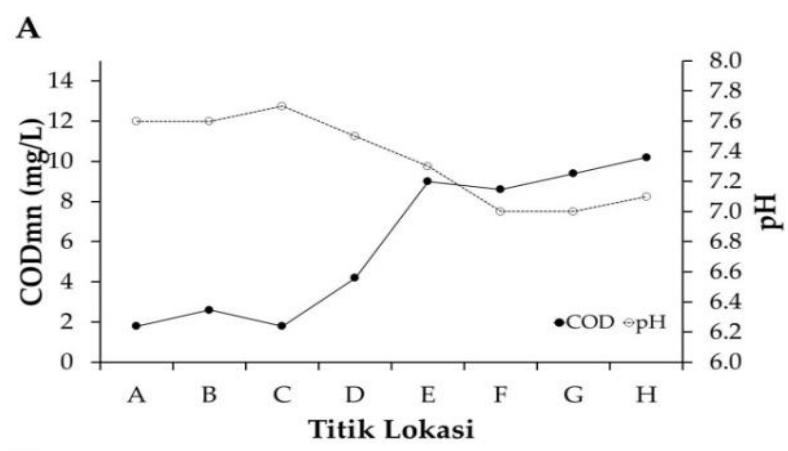

B

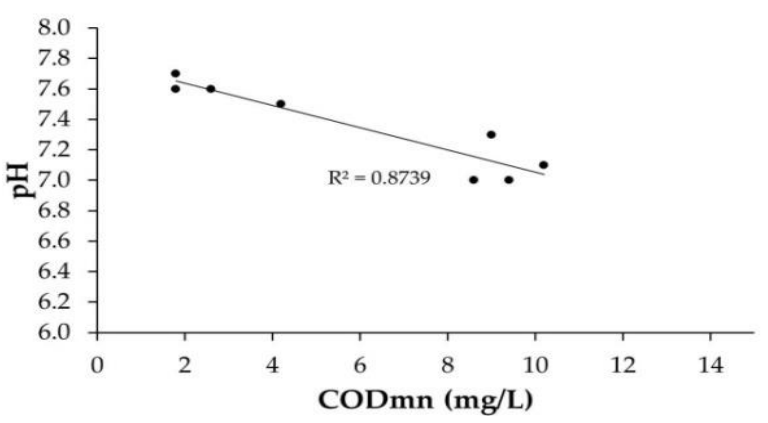

Gambar 2. Kenaikan COD dan penurunan $\mathrm{pH}$ air sungai (A) serta hubungan diantara keduanya (B)

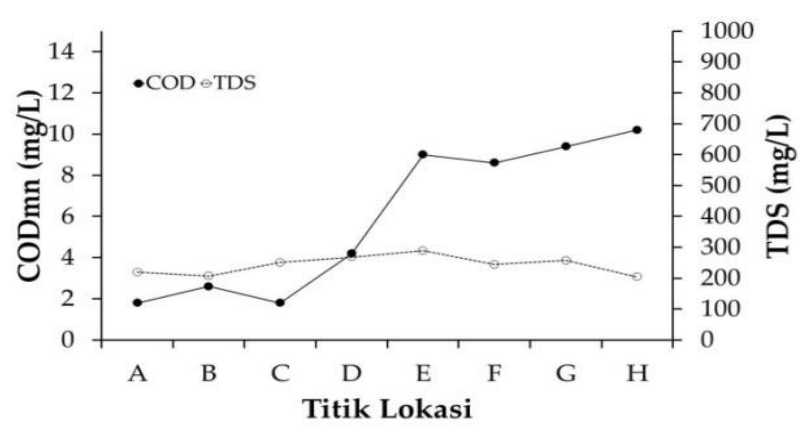

Gambar 3. Laju kenaikan COD dan TDS pada air sungai

\subsection{Kenaikan COD dan TDS air sungai}

Hasil analisa pada kualitas air menunjukkan bahwa walaupun terjadi kenaikan COD, tetapi tidak diikuti dengan kenaikan TDS (Gambar 3). Hal ini mengindikasikan bahwa kenaikan input bahan organik di air sungai tidak diikuti dengan konversinya menjadi bahan inorganik. Berdasarkan hasil analisa dapat diketahui bahwa dengan kenaikan COD dari 2,4 mg/L sampai 6,6 $\mathrm{mg} / \mathrm{L}$, maka terjadi kenaikan hampir 3 kali lipat dengan selisih 4,2 mg/L. Dengan demikian, dengan panjang sungai $18,4 \mathrm{Km}$ maka laju 
kenaikan COD air Sungai Brantas Malang adalah sebesar $2,3 \mathrm{mg} / \mathrm{L}^{-1} \mathrm{Km}^{-1}$.

\section{Pembahasan}

\subsection{Tingkat dan Laju penurunan kualitas air di Sungai Brantas Malang Raya}

Berdasarkan hasil pengamatan diketahui bahwa kualitas air Sungai Brantas Malang terbagi menjadi 3 kelas menurut Peraturan Pemerintah Nomor 82 Tahun 2001 tentang Pengelolaan Kualitas Air dan Pengendalian Pencemaran Air. Titik A, B, dan C memiliki kualitas air kelas 1 dengan nilai CODcr < $10 \mathrm{mg} / \mathrm{L}$. Titik D memiliki kualitas air kelas 2 dengan nilai CODcr $<25 \mathrm{mg} / \mathrm{L}$. Titik E, F, G, dan $\mathrm{H}$ memiliki kualitas air paling rendah (kelas 3) dengan nilai CODcr $<50 \mathrm{mg} / \mathrm{L}$. Berdasarkan hal tersebut dapat disimpulkan bahwa bagian hulu Sungai Brantas Malang memiliki kualitas air yang lebih baik dibandingkan di bagian hilirnya.

Kualitas air di titik A, B, C, dan D relatif lebih baik sebab masih belum mendapatkan input material baik organik maupun anorganik yang dihasilkan dari berbagai akifitas manusia. Titik A dan B masih berada di bagian hulu dari Sungai Brantas Malang yang berlokasi di Kota Batu. Dengan jumlah penduduk yang berkisar 204.000 orang dan jumlah industri formal kurang dari 100 unit usaha (Kota Batu dalam angka 2018), maka tidak akan memberikan dampak yang cukup besar terhadap input material ke dalam aliran Sungai Brantas. Selain itu, wilayah Kota Batu masih didominasi oleh kegiatan pertanian dengan luas lahan 6.600 Ha sehingga dimungkinkan kontribusi input material organik tidak terlalu tinggi. Menurut Yoada et al (2014), limpasan limbah kegiatan pertanian memberikan kontribusi akumulasi bahan organik yang lebih rendah dibandingkan dengan limbah domestik (rumah tangga).

Kualitas air di titik E, F, G, dan $\mathrm{H}$ diketahui telah menurun jauh. Keempat titik ini berada di wilayah Kota Malang yang diketahui memiliki populasi yang cukup tinggi (860.000 orang) dan kegiatan industri yang lebih besar $(>100$ unit usaha) (Kota Malang dalam angka 2018). Menurut Arief (2013), produksi sampah di Kota Malang mencapai 607,44 Ton/hari. Dari keseluruhan jumlah sampah tersebut, $60 \%$ diantaranya adalah sampah organik. Hal inilah yang diduga memberikan kontribusi terhadap kenaikan turbidity dan COD air di titik E, F, G, dan $\mathrm{H}$ (Gambar 1A). Lebih lanjut, Yoada et al (2014) menyatakan bahwa sampah organik dari limbah domestik memberikan kontribusi yang cukup besar terhadap penurunan kualitas air sungai.

\subsection{Pengaruh kenaikan COD terhadap penurunan $p H$ air Sungai Brantas Malang Raya}

Hasil analisa menunjukkan bahwa terjadi penurunan $\mathrm{pH}$ seiring dengan kenaikan COD pada air sungai (Gambar 2A), dan keterkaitan yang erat $\left(R^{2}=0,8739\right)$ (Gambar $\left.2 B\right)$. Hal ini sesuai dengan dugaan bahwa tingginya kebutuhan oksigen kimiawi menunjukkan tingginya kandungan material organik/anorganik yang ada di dalam air. Tingginya konsumsi oksigen tersebut terkait dengan kenaikan produk respirasi berupa $\mathrm{CO}_{2}$ (Wu et al., 2007). Salah satu penyebab penurunan $\mathrm{pH}$ air adalah kuantitas gas $\mathrm{CO}_{2}$ di dalam air yang kemudian akan menghasilkan ion hidrogen $\left(\mathrm{H}^{+}\right)$dan bikarbonat $\left(\mathrm{HCO}_{3}\right)$ (Talling, 2010; Raju et al.,2014). Mekanisme penurunan $\mathrm{pH}$ air terjadi melalui reaksi antara karbondioksida $\left(\mathrm{CO}_{2}\right)$ dan air $\left(\mathrm{H}_{2} \mathrm{O}\right)$ yang kemudian menghasilkan asam bikarbonat $\left(\mathrm{H}_{2} \mathrm{CO}_{3}\right)$. Reaksi itu kemudian berlanjut dengan menghasilkan ion hidrogen $\left(\mathrm{H}^{+}\right)$ dan bikarbonat $\left(\mathrm{HCO}_{3}\right)$ (Nguyen et al., 2008; Hirshberg dan Gerber, 2016).

\subsection{Tingkat dekomposisi bahan organik pada air di Sungai Brantas Malang Raya}

Total dissolved solid (TDS) merepresentasikan keseluruhan padatan terlarut berupa mineral yang ada di dalam air (Islam et al., 2016). Mineralmineral di dalam air sungai bisa disebabkan karena 2 faktor, yaitu input mineral dari luar (Anhwange et al., 2012; Carlson, 2014) dan produk dari dokomposisi bahan organik yang ada pada air sungai tersebut (Wu dan Maskaly, 2018). Titik A, B, C, dan D (Kota Batu dan Malang bagian barat) masih menunjukkan tingkat dekomposisi seimbang, tetapi pola yang sama tidak terlihat pada titik E, F, G, dan H (Kota Malang). Kenaikan nilai COD pada air sungai di wilayah Kota Malang tidak diikuti dengan kenaikan TDS airnya, yang mengindikasikan bahwa kandungan bahan organik pada level tertentu tidak dapat diubah dikonversikan menjadi senyawa inorganik karena terbatasnya kemampuan air sungai untuk melakukan proses sirkulasi material (organic menjadi anorganik). Berdasarkan hasil ini dapat 
diduga bahwa air telah melampaui kemampuan recovery-nya (self purification mechanism) untuk mendegradasi bahan organik pada titik E, F, G, dan H (Cazeless et al., 1991), sehingga nilai TDS terlihat konstan.

\section{Simpulan}

Kondisi air di Sungai Brantas Malang Raya mengalami penurunan secara gradual, dari wilayah Kota Batu sampai dengan Kota Malang. Dengan batasan 18,4 Km panjang Sungai Brantas Malang Raya yang diteliti, diketahui bahwa terjadi penurunan tingkat kualitas air sebesar hampir 3 kali lipat. Adapun laju penurunan kualitas airnya (berdasarkan CODmn) adalah sebesar 2,3 mg.L${ }^{1} \mathrm{Km}^{-1}$. Tiga titik memiliki kualitas air kelas 1 (A, B, dan C), satu titik memiliki kualitas air kelas 2 (D), dan empat titik memiliki kualitas air kelas 3 (E, F, G, dan H). Tingkat dekomposisi bahan organik pada air sungai di wilayah Kota Batu dan Malang bagian barat terlihat masih cukup baik, sedangkan di pusat Kota Malang sudah menurun jauh dan melewati titik jenuh kemampuan recovery-nya (selfpurification mechanism).

\section{Daftar Pustaka}

Anhwange, B.A., Agbaji, E.B., Gimba, E.C. (2012). Impact Assessment of Human Activities and Seasonal Variation on River Benue, within Makurdi Metropolis. International Journal of Science and Technology, 2(5), 248-254.

Arief, S. (2013). Pengelolaan sampah malang raya menuju pengelolaan sampah terpadu yang berbasis partisipasi masyarakat. Jurnal Humanity, 8(2), 195-208.

Bahriyah, N., Laih, S., Syauqi, A. (2018). Uji kualitas air Sungai Metro Kelurahan Merjosari Kecamatan Lowokwaru Kota Malang. E-Jurnal Ilmiah BIOSAINTROPIS, 3(3), 2338-2805.

Baidlowi, I. (2015). Pengaruh aliran air Sungai Brantas terhadap pendapatan petani di daerah aliran sungai (DAS) brantas Kabupaten Mojokerto. Jurnal Review Pendidikan Dasar, 3(1), 351-357.

BAPPEDA Kabupaten Blitar (2015). Kajian Perencanaan Konservasi Daerah Aliran Sungai Brantas. Blitar, Indonesia: Badan Perencana Pembangungan Daerah Kabupaten Blitar.

BPS Provinsi Jawa Timur. (2018). Kota Batu dalam Angka 2018. Surabaya, Indonesia: Badan Pusat Statistik Provinsi Jawa Timur.

BPS Provinsi Jawa Timur. (2018). Kota Malang dalam Angka 2018. Surabaya, Indonesia: Badan Pusat Statistik Provinsi Jawa Timur.
BSN (2004). Cara uji oksigen terlarut secara yodometri (modifikasi azida). Jakarta-Indonesia: Badan Standardisasi Nasional Indonesia.

Carlson, D. (2014). Influence of land use on total suspended solid and dissolved ion concentrations: Baton Rouge, Louisiana area. In the Proceedings of a symposium: Sediment Dynamics from the Summit to the Sea. New Orleans, Louisiana, USA, 11-14 December 2014 (pp. 258-264).

Cazelles, B., Fontvieille, D., Chau, N.P. (1991). Selfpurification in a lotic ecosystem: a model of dissolved organic carbon and benthic microorganisms dynamic. Ecological Modelling, 58, 91-117.

Choi, J., Oh, S., Park, J-H., Hwang, I., Oh, J-E., Hur, J., Shin, H.S., Huh, I-A., Kim, Y-H., Shin, W.S. 2014. Evaluation of CODsed Analytical Methods for Domestic Freshwater Sediments: Comparison of Reliability and Correlationship between CODMn and CODCr Methods. Journal of Environmental Science International, 23(2), 181-192.

Gustafson, H dan Behrman, A.S. (1939). Determination of total dissolved solids in water by electrical conductivity. Industrial and Engineering Chemistry, 11(7), 355-357.

Hirshberg, B. dan Gerber, R.B. (2016). Formation of Carbonic Acid in Impact of $\mathrm{CO}_{2}$ on Ice and Water. The Journal of Physical Chemistry Letter, 7(15), 2905-2909.

Islam, M.R., Sarkar, M.K.I., Afrin, T., Rahman, S.S., Talukder, R.I., Howlader, B.K., Khaleque, Md.A. (2016). A study on total dissolved solids and hardness level of drinking mineral water in bangladesh. American Journal of Applied Chemistry, 4(5), 164-169.

JSA (2016). Testing methods for industrial wastewater (JIS K 0102). Japan: Japanese Standard Association.

Nguyen, M.T., Matus, M.H., Jackson, V.E., Ngan, V.T., Rustad, J.R., Dixon, D.A. (2008). Mechanism of the Hydration of Carbon Dioxide: Direct Participation of $\mathrm{H}_{2} \mathrm{O}$ versus Microsolvation. The Journal of Physical Chemistry, 112(41), 10386-10398.

Republik Indonesia. (2001). Peraturan Pemerintah Nomor 82 Tahun 2001 tentang Pengelolaan Kualitas Air dan Pengendalian Pencemaran Air. Jakarta-Indonesia: Pemerintah Republik Indonesia.

Retnaningdyah, C dan Arisoesilaningsih, E. 2014). Indikasi pencemaran mata air di DAS Brantas hulu wilayah Malang Raya menggunakan Indeks Biotik dari makroinvertebrata bentos. Dalam Prosiding Seminar Nasional Biodiversitas, 3(1), 210-213.

Rusdyi, A.F. (2017). Correlation between conductivity and total dissolved solid in various type of water: A review. In IOP Proceeding Conference Series: Earth and Environmental Science. Global Colloquium on Gesciences and Engineering (pp. 1-6).

Sulistyaningsih, T., Sulardi., Sunarto (2017). Problems in upper Brantas watershed governance: A case study in 
Batu, Indonesia. Jurnal Studi Pemerintahan, 8(3): 383409.

Sylviani (2008). Kajian distribusi biaya dan manfaat hutan lindung sebagai pengatur tata air. Jurnal Penelitian Sosial dan Ekonomi Kehutanan, 5(2), 95-109.

Wu, L., Wwei, C-H., Yang, S-S., Chang, T-H., Pan, H-W., Chung, Y-C. (2007). Relationship between Carbon Dioxide/Methane Emissions and the Water Quality/Sediment Characteristics of Taiwan's Main
Rivers. Journal of the Air $\mathcal{E}$ Waste Management Association, 57, 319-327.

Wu, S. dan Maskaly, J. (2018). Study on the effect of total dissolved solids (TDS) on the performance of an SBR for COD and nitrients removal. Journal of Environmental Science and Health, 53(2), 146-153.

Yoada, R.M., Chirawurah, D., Adongo, P.B. (2014). Domestic waste disposal practice and perceptions of private sector waste management in urban accra. BMC Public Health, 14(697), 2-10.

(C) 2018 by the authors; licensee Udayana University, Indonesia. This article is an open access article distributed under the terms and conditions of the Creative Commons Attribution license (http://creativecommons.org/licenses/by/3.0/). 